\title{
History of professional education on podiatry emergencies and disasters: a Spanish point of view
}

BY DANIEL LÓPEZ LÓPEZ, ROSA MARY DE LA CAMPA PORTELA, MARTA ELENA LOSA IGLESIAS, MATILDE GARCÍA SÁNCHEZ, JOSÉ RAMOS GALVÁN, CARLOS AGRASAR CRUZ, RICARDO BECERRO DE BENGOA VALLEJO

\section{Abstract}

Mainstreaming between podiatry practice and podiatry studies is needed. Podiatry practice evolution in Spain has allowed this medical discipline to obtain its own academic, institutional and legislative framework to increase and improve professional decisions in the podiatric medical practice. For that reason, there is a great interest and relevancy on emergencies and urgencies education in podiatry clinical and welfare activity. It is an essential component, the different and inherent risk conditions of welfare activity require to give an immediate, accurate and sure response that protects people life. Podiatry faculties could and should establish joint actions that integrate on an effective way the complexity and multiplicity of vital situations that the podiatric activity involves, as well as to establish strategic plans in the activity of professional podiatrists that come together in an improvement of 
graduates.

Key words: education, Emergency medicine, podiatry, disasters

\section{Point of View}

Emergencies and disasters (EA) are areas in expansion and of vital importance for the society, which make possible improvements and the existence of scientific paradigms in several areas of health such as biology, medicine, podiatry, odontolgy, among others. So it is necessary to obtain a high degree of training to be able to undertake efficiently the special complexity and multiplicity of vital situations that welfare activity implies, giving an immediate, accurate and sure response that protects people's life. (1)

The current difficulties linked with the demographic pattern change, with a population increasingly fragile that presents a higher risk and added complexity in case of any imbalance in their health, (2) makes the launching of new scenes necessary, which result in the increasing of new challenges on health issues and new efforts to implement actions aimed primarily to the field of EA and to the field of health in general.

Podiatry is immersed in these difficulties since it is a part of the multidisciplinary team of health in different areas such as undergraduate, graduate, postgraduate and continuing medical education and training. Also podiatry is involved in research areas and takes part in innovation, development and transfer of results. In the welfare field podiatry is in contact with health care and improvement. With regard to the institutions, podiatry transmits new sustainable and healthy policies providing, among other questions, professional legislative codes. (3) In this respect, EA constitute the welfare quality reference model in the search for providing strategic lines and approaches that guarantee the clinical safety and / or the patient care.

Therefore, if we go back to the inaccurate historical records of emergencies and disasters, the link between welfare and technology 
models is established. This link is shown through the professional labor of those who devoted themselves to health care and relationships with patients taking on an activity of vital importance connected to survival and decrease of global mortality and developed firstly at hospitals and out-of-hospital later. (4) For that reason the need to study emergencies and disasters related to the podiatric practice and the diversity of skills and responsibilities of vital importance linked to these situations appeared. (5) Among these skills and responsibilities are diagnosing and treating foot injuries and deformities (burns, puncture wounds, lacerations, sprains, strains, fractures, dislocations, and amputations), prescribing drugs for podiatric medical disorders, performing and interpreting radiographs and the administration of local anesthetics, which can unleash between 5-10 \% adverse side effects. Anesthetics administration is an integral part of the daily podiatric medical practice in the operating room and podiatric physicians must be conscious of the specific side effects that can appear and how to handle these reactions in the welfare environment. (6) In the field of assistance in major disasters there is previous experience with the American podiatric physicians who, after the terrorist attack to the World Trade Center Twin Towers of New York, set up almost immediately a Podiatric Field Hospital where the podiatric injuries of victims, firemen and volunteers were attended. (7)

In addition, the importance of medical problems, joined to the increase of biomedical advances, the complexity of the podiatric activity, the workload and economic pressures have resulted in a higher demand for the podiatric physician, often experiencing the requirements and the prioritization of safety and support topics as a necessary part of clinical practice. (8)

Though, podiatric medical students pay few attention to emergencies and disasters, it is necessary to consider that emergencies and disasters management can be learned at university, and this will be positive for the podiatric physicians, while they can contribute in podiatric medical education training podiatric medical students in aspects related to a series of specific skills on disasters and, even more, on emergency fields. To that end the implantation of a plan of staff rotation in primary health 
care emergency departments would be necessary as it happens with primary care physicians (9) or the establishment of a postdegree education that guarantees the innovation and development focused on Clinical safety and / or patient care.

The lack of strategies of podiatric physicians to face risk and survival conditions demonstrates the interest of students with regard to emergencies, disasters and survival issues, by means of paradigms explained with different methodologies, to generate a debate between students and teachers as in the case study methodology, which takes place in the teaching - learning process to establish recognize usual medical complications such as asthma, chronic obstructive pulmonary disease, diabetes, hypertension, together with other unexpected emergencies such as anxiety, convulsions and syncope. (10) Due to the fact that most podiatric procedures are performed with patient in state of consciousness, they often are afraid and have apprehension and podiatric physician must take into account that fear and pain can cause vasovagal reactions and be prepared to provide a therapy of support to help the patient to return safely to a normal condition of consciousness. (6)

The contribution to the improvement on emergencies and disaster education should allow the student to promote and develop new skills looking for generating a regular training on clinical situations and on simulated scenes. This training should provide to the intervention team the necessary skills to be able to develop an efficient welfare labor within the minimum required quality standards and to assure a quality continuing education of podiatric physicians. (11)

Therefore, the education of podiatric physicians has to establish an additional education orientated to resolve the problems that appear in the welfare podiatric activity to a general level. In a special way, emergencies and disasters will be a providing model in the educational action capable of guiding students in conflicts resolution and helping them to obtain the necessary skills to be good physicians. This is due to the complexity of managing these patients, the high anxiety generated by the scene of these circumstances, their impact and the quick decision 
making process involved, which forces physicians to adapt to clearly established and regulated methodological processes. (12)

With such a purpose, the podiatry student has to receive information based on these processes to contribute to the development of a global and wide vision in which there is qualified personnel prepared to respond to emergency situations and to offer the necessary guarantees in the different job opportunities of this professional career, focused on teaching, research, management and welfare practice among others.

Podiatric physicians have a special interest in public health and in the adoption of measures to guarantee that podiatry turns into an integral part of healthcare system, contributing with the community through activities and public health policies on a general level and particularly on emergencies and disasters. (13) The participation of podiatric physician at the moment of safeguarding clinical safety and patient care should be a general level skill to be demonstrated within the multidisciplinary healthcare team that should showcase the competences and protocols particularly at the moment of receiving directly the patients. (14)

The identification on the part of podiatric medicine of a huge range of situations related to emergencies and disasters such as the moral distress, the organization of tasks, the patients' demands, the scarce of time available, the lack of human resources, the dilemmas of oldness, pain, death, palliative care, euthanasia, the right to a dignified death, the distribution of resources, the defense of patients' autonomy, the research, the patient - podiatric physician relationship, the informed consent, confidentiality, the honest communication with patients, the professional responsibility on patient health and the humanization of care, that joined to the lack of strategies to confront the priority related to clinical safety relevancy and / or patient healthcare, they reveal the need of answers in common aspects of the daily practice, to make easier the podiatric physician practice. (15)

The evolution of podiatric career in Spain is a consequence of the institutional and legislative frames and the social demand, due to the 
lack of specialized care for foot health until the birth of this health discipline. (16) The obtaining of its own legislation gives to podiatric physicians disciplinary measures to carry out with the purpose of safeguarding the profession and the patients.

The Spanish law on sanitary professions arrangement defines podiatric profession as: physicians who realize the activities aimed to the diagnosis and treatment of feet illness and deformities, by means of its own speciality technologies. This law indicates that ethical problems will be treated by the General Council of each profession (in this case podiatric profession), which applies its own rules according to its particular ethical code, independently of other measures considered necessary by other institutions. (17)

For example, in article 1, paragraph 6, the Ethical Code of Spanish Podiatric Physicians indicates: Podiatric Physicians not only must take care of persons foot health, but they have to take responsibility for their training on technical and scientific advances related to their specialities, in order to offer a good welfare quality according to science condition. (18)

Therefore, the synergies between podiatric professional education and the emergencies and disasters are of vital significance in the frame of higher education, being the Faculties of Podiatry the institutions in charge of establishing joint actions that effectively integrate the complexity and multiplicity of vital situations that podiatric practice implies, to enable podiatry graduates an empowerment of knowledge focused on clinical safety and patient care.

The new changes happened in the European education that gave rise to the new European Space for higher Education, and to the transformation of the Spanish qualifications leading to their standardization, has the purpose of facilitating the free mobility and exchange of students and graduates between European countries. The standardisation of podiatry studies in Europe, joined to new official podiatry postdegree programs, are an incentive for the development of EA issues in the academic 
programme, which contributes to an increase of the European students' knowledge on podiatry in emergencies field.

\section{References}

1. García Menéndez MA, Toranzo Cepeda T. Emergencias 2012;24:332-4.

2. Díaz Acosta J, Sanz Villorejo J. El futuro profesional de la enfermería de urgencias y emergencias española. Emergencias 2010;22:163-4.

3. López López D, Ramos Galván J, Alonso Tajes F, García-Mira R. Manual de Podología y Salud: Conceptos, Aspectos Psicológicos y Práctica Clínica. Madrid: CERSA, 2012.

4. Pacheco Rodríguez A, Alvarez García A, Hermoso Gadeo FE, Serrano Moraza A. Servicios De Emergencia Médica Extrahospitalaria En España (I) Historia y Fundamentos Preliminares. Emergencias 1998;10:173-8.

5. Levy LA, Jones LJ. Educating the Podiatric Physician in Disaster and Emergency Preparedness. J Am Podiatr Med Assoc 2012;102(6):512-6.

6. Grambart S, Decker TL. Common Office Emergencies. Clin Podiatr Med Surg 2002;19(1):163-5.

7. 9/11 MEMORIAL: Recovery Stories. Acceso el 13 de enero de 2015. Disponible: http://www.911memorial.org/recovery-stories

8. Losa Iglesias ME, Becerro de Bengoa R, Salvadores P, Trepal J. Comparative Analysis of Moral Distress and Values of the Work Organization Between American and Spanish Podiatric Physicians. J Am Podiatr Med Assoc 2012;102(1):57-3.

9. Alonso Mateos Rodríguez A, Pardillos Ferrer L, Montarelo Navajo A, De La Parte De La Fuente B, Peñuela Melero S, Vázquez Quiroga B, Huertas Alcázar P. Programa de formación de residentes en un sistema de emergencias extrahospitalarias. Emergencias 2010;22:144-0.

10. Wald DA, Wang A, Carroll G, Trager J, Curtis M, Cripe J. A Blueprint for an Office-based Emergencies Course. J Am Podiatr Med Assoc 2012;102(4):343-9.

11. Grupo de trabajo «Proceso Asistencial Trauma Grave» de EPES. Informe inicial (Documento cero). Empresa Pública de Emergencias Sanitarias. Consejería de Salud. Junta de Andalucía. Abril 2008.

12. Ayuso F, Nogué R, Coll Vinent B, Fernández Esáin B, Miró O. Docencia 
en medicina de urgencias y emergencias. An Sist Sanit Navar 2010;33(1):203-3.

13. Walter Psoter W, Glotzer DL, Baek LS, Karloopia R, Morse DE. Podiatric Medicine and Disaster Response. A Survey of the Professional Leadership. J Am Podiatr Med Assoc 2013;103(1):87-3.

14. Levy LA. Natural and Man-made Disasters: Where Is Podiatric Medicine? J Am Podiatr Med Assoc 2006;96(4):378-9.

15. Losa Iglesias ME, Becerro de Bengoa R. Musculoskeletal Pain, Job Satisfaction, Depression, and Anxiety Among Spanish Podiatric Physicians. J Am Podiatr Med Assoc 2014;104(2):191-7.

16. López López D. Podología y Salud: un análisis de las representaciones sociales de las enfermedades del pie desde una perspectiva psicosocial. A Coruña: Servizo de Publicacións da Universidade da Coruña. 2011.

17. Boletín Oficial del Estado. Ley 44/2003, de 21 noviembre, de la certificación de las profesiones sanitarias. Disponible en: http://www.boe.es/buscar/doc.php?id=BOE-A-2003-21340.

18. Código Deontológico de la Podología. Madrid: Consejo General de Colegios Oficiales de Podólogos. 2013. p2.

Daniel López López Departamento de Ciencias da Saúde Universidade da Coruña Unidade de Investigación Saúde e Podoloxía Campus Universitario de Esteiro s/n 15403 Ferrol, España E-mail: daniellopez@udc.es

Article printed from Signa Vitae: http://www.signavitae.com URL to article: http://www.signavitae.com/2016/o5/history-ofprofessional-education-on-podiatry-emergencies-anddisasters-a-spanish-point-of-view/

Copyright (C) 2015 Signa Vitae. All rights reserved. 